\title{
Ritual Ablution and Cultic Purity in an Ismaili Context: The Siğistānian View
}

\author{
ANTONELLA STRAFACE (University of Naples "L'Orientale”)
}

\begin{abstract}
The paper, which is a continuation of my previous research on the Siğistānian view of the pillars of Islam, aims at analysing the interpretation of ritual ablution $\left(w u d \bar{u}^{\prime}\right)$ and cultic purity (tahāra) according to the tenth-century Ismaili $d \bar{a}^{c} \bar{l}$ Abū Ya'qūb al-Siğistānī. In the last of his works, the Kitāb al-iftih̆ār (The Book of the Boast), this outstanding Ismaili missionary also devoted attention to the Islamic ritual prescriptions. These obligatory duties, whose performance al-Siğistānī fully recognised, conceal an inner meaning that can be unveiled through the tradition of the $t a^{\prime} w \bar{l} l$, the esoteric interpretation that, according to the Ismaili doctrine, allows the mu'min to achieve his salvation.
\end{abstract}

Key words: Ismailism, pillars of Islam, ritual ablution and cultic purity, $t a^{3} w \bar{l} l$

\section{Introduction}

The Ismailis represent the second largest Shic $i$ community after the Itnā'ašariyya (the Twelvers) and, although they have greatly contributed to the developing of Islamic thought, their long history was almost unknown and not adequately understood until recent times.

Often persecuted, in particular outside their territories, the Ismailis were compelled to resort to the taqiyya, the precautionary dissimulation of true religious belief, especially in times of danger; this principle was also conceived by the Ismailis as the duty of observing secrecy $($ kitmān $)$ on the doctrine and on the identity of the imam. The central position of this issue in the Ismaili doctrine is linked to the role assigned to the imam, who is the only one able to apply the spiritual exegesis $\left(t a^{\prime} w \bar{l} l\right)$ to the Quran, thus assuring the gaining of Truth. This is why the role of the imam was considered absolutely 'necessary'.

This Truth, which is disguised in rites and prescriptions of the official religion and which is not available to those outside the Ismaili community (the exoteric people, ahl al$z \bar{a} h i r)$ nor to the $\check{g} u h h \bar{a} l$ (those who ignore the inner meaning of the Revelation), must remain hidden until the qiyäma, that is the manifestation of the unveiled Truth through the $\mathrm{Q} \bar{a}^{3} i m$; in waiting for this event, the Quranic prescriptions remain in force.

So, despite the common belief of the majority who, based on anti-Ismaili writings of polemicists and heresiographers (notably those of Ahū Muhsin, al-Bag̀dādī, Ibn Hazm and al-Ġazāili), condemned the Ismailis as heretics, the Ismailis recognised, at least formally, that full value should be given to the obligatory duties prescribed by the sharia, including, especially, the pillars of Islam. On the other hand, these duties symbolise a Truth, one and unchangeable, that no mu'min should disregard.

Journal of Arabic and Islamic Studies 17 (2017): 268-279 
Starting from this premise, the tenth-century Ismaili $d \bar{a}^{c} \bar{l}$ (missionary) Abū Ya'qūb alSiğistānī wrote, towards the end of his life, the Book of the Boast, in which he gave an overall picture of the Ismaili teachings so as 'to boast' (hence, the title of the treatise) about the merits of the Ismailis, who were considered to obey the Quran to the letter as well as to the spirit.

\section{Abū Ya'qūb al-Siğistānī: his life and works}

The biographical details of Abū Ya'qūb al-Siğistānī (d. after 361/971) are very scarce and uncertain since he was compelled, like his predecessors, to perform his function of $d \bar{a} \bar{l}^{-1}$ clandestinely. From Sistān, where he was born, al-Siğistānī moved to Rayy where he succeeded Abū Haatim al-Rāzī (d. 324/934?) in directing the da'wa (the 'propaganda'). ${ }^{2}$ The date of his death is uncertain too; from a clear allusion contained in the Kitāb al-iftiha $\bar{a} r^{3}$ he was probably still alive in 360/971, a hypothesis that seems to be plausible since, according to some sources, al-Siğistānī was killed when Hurasān came under control of Mạ̣mūd of Ġazna in 392/1002. Thanks to his works, ${ }^{4}$ modern scholars have been able to reconstruct the first developments of philosophical Ismailism, although the details of its origins remain somewhat unclear. ${ }^{5}$

Al-Siğistān̄̄ represents, after Abū Ḥātim al-Rāzī and Muḥammad b. Aḥmad al-Nasafī (d. 334/943), the last of the Ismaili $d u^{c} \bar{a} t$ (missionaries) of early generations, who were

1 Lit. 'the one who summons', the Ismaili $d \bar{a} \hat{\imath}$ was charged with the spreading of the Ismaili teachings $\left(d a^{c} w a\right)$ and with the recruiting of neophytes and their initiation into the secrets of the doctrines; moreover he was responsible for the oath of loyalty to the imam that every recruit must swear. As for the spreading of the Ismaili teachings, it was carried on through a highly sophisticated system of propaganda, which aimed to win followers to the imam. For an outline of the figure of the $d \bar{a}^{c} \bar{l}$ and the organisation of the dac wa see DAFTARY 1993; TAJDDIN SADIK ALI 2006; HALM 1996, esp. ch.1.

2 Information on the real functioning of the $d a c w a$ is rather scarce, because in most cases the Ismailis were compelled to operate clandestinely, notably in regions outside the Fatimid dominion. As Farhad Daftary pointed out: "the da'wa organization and its hierarchy of ranks ( $h u d \bar{u} d)$ alluded to in various Ismaili text of the Fatimid period seem to have applied to an idealised or utopian situation when the Ismaili imam would rule the entire world, and not to any actual system'. DAFTARY 1998: 97.

3 See footnote 15.

4 Besides the Kitāb al-iftihār, al-Siğistānī also wrote Kitāb al-mawāzin, Kitāb ițbāt al-nubuwwa, Kitāb

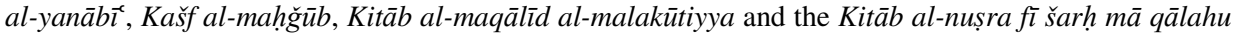
al-šayh al-Hamīd fi Kitāb al-mahșūl. This last-mentioned work was written in response to Abū Hātim al-Rāzī, with whom he came into conflict with regard to some issues related to the duration of the prophetic cycles, in particular with the duration of the sixth era, the era of Islam.

5 The complexity of the studies on Ismailism is mainly due to the esoteric nature of its doctrine but also to the lack of primary sources, especially those antecedent to the Fatimid era $\left(4^{\text {th }} / 10^{\text {th }}\right.$ century), a period that is supported by documentary evidence. The difficulty in gaining access to primary sources makes the reconstruction of Ismaili historical and doctrinal evolution very complicated. Notwithstanding, during the last decades, the studies of the most authoritative scholars (such as Ismail Poonawala, Wilferd Madelung, Heinz Halm, Paul E. Walker, Azim A. Nanji, Farhad Daftary and Daniel De Smet, to quote the most recent generation of researchers) have greatly contributed in clarifying many aspects of Ismaili doctrine. For bibliographical details on Ismaili studies see DAFTARY 2004. 
charged with political and doctrinal activities. On the doctrinal level, he can be considered a pioneer of philosophical Ismailism because he provided a relevant contribution to the shaping of a doctrine that Islamicised Neoplatonism. ${ }^{6}$

On the political level, al-Siğistānī became a high-ranking $d \bar{a}^{c} \bar{\imath}$ of Fatimid propaganda. This important function of control implies that he acknowledged, despite his originally belonging to Qarmatism, ${ }^{7}$ the Fatimid a $^{3}$ imma as legitimate representatives of the Qẩim (lit. he who will rise), ${ }^{8}$ probably in a formal way or, at least, until the Qā'im's advent. This involves that, in waiting for his return, the Islamic sharia remained in force. Hence alSiğistāni recognised the full value of the obligatory performance of the Islamic rituals and prescription, first of all the pillars of Islam; at the same time, he supported a doctrine that considered rituals, prohibition and commandments the shell (qišr) that conceals and safeguards the Truth hidden in the Revelation.

In this regard, it is worth noting that Ismailism has its doctrine grounded in the immanent duality in all of the features of the reality, including the Scripture. This involves that the Word of God has two aspects, one manifest (zāhir) and the other hidden (bātin): the first can be attained through the tanzill, the second through the $t a^{\prime} w \bar{l} l$. This spiritual exegesis, which can be performed only by the imam, is the only way to unveil the Truth that lies disguised in rites and prescriptions of the official religion: in other words, according to Ismaili teaching, the formal performance of the cultic practices is not sufficient to gain salvation.

This soteriological purpose can be achieved only through the understanding of the true meaning of what God prescribed in Revelation, as highlighted by al-Siğistānī who, in the last of his works, the Kitāb al-iftihāar (The Book of the Boast), interpreted esoterically the arkān al-isläm, to which he devoted the last chapters of his treatise.

6 In particular, al-Siğistān̄ established a cosmology in which God was conceived as totally transcendent Unlike the Neoplatonic cosmology, in the Siğistānian system, God, because of His transcendence, did not emanate spontaneously but immediately created ex-nihilo $\left(a b d a^{c} a\right)$ the Intellect (also called the 'first originated', al-mubda' al-awwal). The Intellect, in its turn, emanated (inba'ata) the Soul, who produced (inbağasa, lit. to gush out) Nature, from which Matter and Form came forth. The mixing of both was responsible for physical beings. For details on the Siğistānian cosmology see WALKER 1993 and 1996.

7 A branch of the pre-Fatimid Ismailism, this revolutionary movement of social reform and justice, which was based on a system of gradual initiation, carried on its doctrine in strict secrecy. Although its origin is obscure, scholars agree that the movement began its activity in southern Iraq in the second half of $3^{\text {th }} / 9^{\text {th }}$ century, when its partisans, led by Ḥamdān (the eponym of the group), founded a dār al-hiğra east of Küfa in 277/890. Sweeping through the Muslim world from the $3^{\text {th }} / 9^{\text {th }}$ to the $6^{\text {th }} / 12^{\text {th }}$ century, the Qarmatians established an independent State in Bahrayn in 286/899, that is, after the split of Salamiyya, which brought about the formation of the Fatimids and the Qarmatians. The reason for the schism was related to the idea of the imamate, that the Qarmatians considered an intellectual characteristic to which every Muslim can aspire rather than an inherited privilege for the chosen few.

8 This 'messianic' saviour, called also mahdī (the rightly guided one), was charged, during the 'period of concealment' (dawr al-satr), with the soteriological function of restoring justice and true religion. For an outline of the role of this important figure for Ismailism, see DAFTARY 2010; TUCKER 2008. 


\section{Wựū' and țahāra in the Kitāb al-iftihār}

The Kitāb al-iftiha $r{ }^{9}{ }^{\text {p }}$ probably written in $361 / 971$, is an important primary source in the absence of other and earlier Ismaili works; moreover, it can be considered an epitome of Ismaili teachings, which al-Siğistānī expounded in a systematic way, a very unusual behaviour for an Ismaili author as Ismailis were usually compelled to spread the doctrine with great caution.

Al-Siğistānī explicitly maintained that the necessity for defending the Ismaili community from the accusation of professing doctrines in contrast to the true beliefs of faith induced him to provide the basic tenets of Ismaili creed so as to 'boast' the merits of the Ismailis who, unlike their opponents, obey the Word of God to the letter (zāhir) and the spirit (bātin), as the interpretation of the ritual practices, such as the pillars of Islam, shows.

The discussion of this issue was intended to prove that the pillars must be understood symbolically: as a matter of fact, al-Siğistānī explained that, according to the Ismaili interpretation, prayer must be interpreted as the calling to the dac $w a$ and to its spiritual and religious ranks, ${ }^{10}$ fasting involves the duty of observing secrecy about the imam's identity and Ismaili teachings, almsgiving must be interpreted as the duty to bestow knowledge on those who do not possess it and pilgrimage represents obedience to the imam, who is considered the house of God (Ka'bat Allāh).

The analysis of the pillars begins with ritual ablution (wud $\left.\bar{u}^{\prime}\right)$ and cultic purity (tahāra), which is the topic of the present study, ${ }^{11}$ since they are considered the first of the acts prescribed by the Islamic law' (awwal a'māl al-šarī'a).

Chapter 13 of the treatise concerns 'the understanding of ablution and ritual purity' ( $f i$ ma 'rifat al-wuḍ $\bar{u}^{\prime} w a ' l$-tahāra). At the beginning of the discussion al-Siğistānī addresses the exoteric people (ahl al-zāhir) in a polemical tone, because, according to him, they perform mechanically the cultic practices prescribed by Revelation without understanding their true sense, that is, their esoteric meaning.

So, if ablution ( $\left.w u d \bar{u}^{\prime}\right)$ on the exoteric level is the cleansing (bara'a) of any kind of impurity, from the esoteric point of view it must be understood as the disavowal of those who did not recognise the necessity for the imam and the imamate. Those 'renegades', who seized legitimate power, are considered by al-Siğistānī to be just like other material impurities from which true believer must purify. On the other hand, cultic purity (tahāra) is the metaphorical image of heart's purity, which is indispensable to achieve the supreme goal, that is, the knowledge of Truth.

9 The Kitāb al-iftihāar (hereafter Iftihāar) was edited twice. Firstly, Mușțafā Gālib published the Kitāb aliftihär (Beirut 1980) in an incomplete version in which he omitted the offensive passages of condemnation of the Ismailis' opponents. Later, Ismail Poonawala published a new edition of the treatise (Beirut 2000), which he supported with a comprehensive introduction and commentary. In the following analysis, I shall refer to both versions. Translations of the passages quoted are mine.

10 Ismaili 'propaganda' ( $\left.d a^{c} w a\right)$ provided for two kinds of hierarchies, heavenly and earthly, each of them divided in five ranks ( $h u d \bar{u} d$ ). For details see below, p. $273 \mathrm{f}$.

11 This paper is a continuation of my previous research on the Siğistānian interpretation of the pillars of islam, in particular on prayer, almsgiving and fasting. For details see STRAFACE 2016a; 2016b; 2017. 
In performing wud $\bar{u}^{\prime}$ and tahāra, water plays a fundamental role, because cleanliness from impurities can be achieved only through it. According to the Ismaili interpretation, water too must be understood metaphorically: since the disavowal and denial of the imam are the worst of the impurities, as mentioned earlier, the only 'water' that can cleanse one from this kind of impurity is knowledge ( ${ }^{\mathrm{ilm}}$ ). So, if water makes the muslim gain the cleanliness indispensable to perform prayer, knowledge allows the mu'min to achieve his salvation. Through knowledge the believer purifies his heart from doubts ( $\breve{s} u k \bar{u} k)$ and quarrels (ihtilāfät) that prevent the achievement of certainty (yaqīn) and truth (haqīqa). ${ }^{12}$

In order to legitimise the esoteric interpretation of cultic purity and water, al-Siğistānī refers to the following Quranic verse:

Remember He covered you with a sort of drowsiness, to give you calm as from Himself, and He caused rain to descend on you from heaven, to clean you therewith, to remove from you the stain of Satan, to strengthen your hearts, and to plant your feet firmly therewith. ${ }^{13}$

According to the literal interpretation, this verse alludes to the battle of Badr, a key struggle in the early period of Islam that ended in favour of Muhammad, thanks to divine intervention. $^{14}$

In al-Siğistān̄̄’s view, this verse must be interpreted esoterically because the true meaning of this revelation goes beyond the importance of an historical event from which later generations do not learn ( hikma) anything, 'since it occurred 350 years ago'. ${ }^{15}$ Moreover, if the water quoted in this passage must be understood literally why, al-Siğistān̄i asks, did God relate it to the 'stain of Satan, the strength of the hearts and the planting feet firmly'? Hence, al-Siğistānī concludes, the verse must be interpreted metaphorically, as follows: God gave believers knowledge (= rain, $m \bar{a}$ ) by means of His messenger (= 'from heaven', min al-sam $\vec{a}^{\prime}$ ) so as 'to destroy the quarrels of the adversaries who changed religion and corrupted it through their illations $(\bar{a} r \bar{a})$ and conjectures (qiy $\bar{a} s) \cdot{ }^{16}$ In this way, the hearts of believers should be freed from doubt ( $\check{s} a k k)$ and ambiguity ( $\check{s} u b h a)$ because their intellects, strengthened by knowledge, should gain a foothold (= 'to plant feet firmly', yutabbit bihi 'l-aqdām), 'out of any feeling of uncertainty (rayb) and ambiguity'. ${ }^{17}$

This implies that only knowledge can remove any form of ignorance, doubt, uncertainty and ambiguity because, in unveiling Truth that is hidden in the revealed Scripture, it assures certainty and salvation. This is why knowledge is connected with the imam who, being its repository, is charged with the soteriological purpose of the Ismaili teachings.

12 See al-SIĞISTĀNĪ 1980: 111; 2000: 232.

13 Quran 8:11. For the Quranic translation see ALI 2001.

14 On the authority of some versions, Muslims encamped on a dry, sandy and unstable terrain that God makes stable by making rain descend on it, so as to facilitate them in the struggle with their opponents.

15 See al-SIǦISTĀNİ 1980: 111, 22; 2000: 233, 8-9. This biographical detail, explicitly mentioned by the author, helps to determine when al-Siğistānī wrote his treatise, that is, between 360/971 and 364/974 (since the battle of Badr occurred in 2/624).

16 See al-SIǏISTĀNĪ 1980: 112,16-18; 2000: 234,10-11.

17 al-SIĞISTĀNī 1980: 111,21; 2000: 235,1-2.

jais • 17 (2017): 268-279 
As regards the drowsiness ( $\left.n u^{c} \bar{a} s\right)$ quoted at the beginning of the aforementioned verse, al-Siğistānī interprets it as the $b \bar{a} t \underline{t} i n \bar{\imath} /$ hidden aspect of Revelation (just as the wakefulness is the $z \bar{a} h i r \bar{i} / m a n i f e s t$ aspect of Scripture), the knowledge of which is 'a safety and a protection from the Torment, that is, doubt and confusion (hayra) ${ }^{18}$ for believers.

The spiritual value of water and ablution is also restated in another Quranic verse: '[...] And Allah only wishes to remove all abomination from you, ye members of the Family, and to make you pure and spotless. ${ }^{, 19}$ According to the esoteric interpretation, this quotation acknowledges the 'pure and spotless' condition only in the Ahl al-bayt, ${ }^{20}$ that is, the a'imma, laying emphasis on such a fundamental issue of the Ismaili creed that teaches the status of infallibility and impeccability ( ișma) not only for the messenger of God but also for the imam. This condition of purity is achieved only through a spiritual water (knowledge) that has nothing to do with the natural water of wells and springs, ${ }^{21}$ as maintained in the Quran, that quotes: '[...] and We send down pure water from the sky, that with it We may give life to a dead land, and slake the thirst of things We have created,cattle and men in great numbers. ${ }^{22}$

This verse, according to al-Siğistānī, implies that God revealed through His messenger (= 'from the sky') the knowledge (= 'pure water') that will remove (= 'give life') the impurity of ignorance (= 'a dead land'). This knowledge will be granted only to those who deserve it, that is, the a'imma and the lawähiq (Adjuncts), represented in the verse as 'thirst of things [...],- - cattle and men in great numbers'. This is a further confirmation, according to al-Siğistānī, that the water here mentioned is not that of the natural springs that is destined, on the contrary, for all the creatures and not the chosen few.

Al-Siğistānī also applies the tradition of $t a^{3} w \bar{l} l$ to the body that is purified during ablution; as a matter of fact, its parts, which are washed during this ritual practice, represent the ranks $(h u d \bar{u} d)$ of the Ismaili hierarchy.

As previously hinted at, Ismaili propaganda provided for two kinds of hierarchies: heavenly and earthly. The heavenly hierarchy, echoing Neoplatonic doctrines, included five ranks, namely: the Intellect (established by God through His divine command kun, 'be!'), the Soul (emanated by the Intellect) and three hypostases, namely al-Ğadd, al-Fath and alHayāl (which perform a noetic function). ${ }^{23}$ The earthly order provided five ranks too, namely: (1) the Prophet, called also 'Speaking' (Nätiq) because he was in charge of the revelation (tanzīl) of God's Word, (2) the 'Foundation' (Asās), known also as 'Silent' (Sāmit) because he safeguarded the concealed meaning of the divine Word, and (3) the

18 al-SIĞISTĀNĪ 1980: 112,10-11; 2000: 234,4.

19 Quran 33:33.

20 Lit. 'People of the House', this statement refers to the family of the prophet Muhammad, although in the course of time a debate arose on the people who belong to it. In shici Islam the 'People of the House' consist of the Ahl al-kisä', or the 'People of the Mantle' (that is the Prophet, his cousin and brother in law, 'Alī, his daughter Fāṭima and his nephews, al-Ḥasan and al-Ḥusayn) and their progeny of a'imma who, being sinless and infallible, were qualified to perform the spiritual function they were charged with.

21 See al-SIĞISTĀNī 1980: 112,23; 113,1; 2000: 235,5-6.

22 Quran 25:48-49.

23 For details see DE SMET 2012. 
Imam, the Prophet's delegate, who keeps the secret of the esoteric interpretation ( $\left.t a^{\prime} w \bar{l} l\right)$ of the Scriptures in every generation, and preserves it. This triad was followed by the 'Adjunct' (Lāhiq), the imam's delegate, and the 'Wing' ( $\breve{G} a n \bar{a} h$ ), his assistant. The control of the Ismaili community and the recruiting of neophytes were carried on by a series of missionaries $\left(d u^{\prime} \bar{a} t\right)$ and licentiates $\left(m a^{\prime} \underline{d} \bar{u} n\right)$. The hierarchical structure of the terrestrial system, which reproduced the superior-celestial order on earth, aimed at ensuring support for the community, not just material, so as to assure the community its salvation.

According to al-Siğistān̄, body's limbs, which are purified by water during ablution, are related to the aforementioned ranks. So, the right hand is put in relation to the teacher who guides to the right path' (al-hādi al-mu'allim), the left hand is connected with 'the one who searches for knowledge' (al-tālib al-murtād) and the nostrils that inhale water during ablution are related to the Lord of Time (sạhib al-zamān), who grants the Adjuncts (lawāhiqu) his inspiration (ta'yīd). Al-Siğistānī explains these correspondences in the following way:

Since the seeker (al-murtād al-bāhit $)$ the features of his religion cannot do without a guide who leads him on the right path and shows him what he intended to know of it (sc. religion), the right hand provided evidence of the teacher who guides to the right path, the left hand [provided] evidence of the seeker who investigates and the water that passes between them, so as the one [hand] cleans the other, [provided] evidence of the knowledge that passes between them (sc. teacher and pupil) at the moment of disclosure (waqt al-mufätaha). ${ }^{24}[\ldots]$. After having washed the hands, the one who performs ritual ablution begins to rinse, that is to put water in the mouth, and the mouth is the locker of tongue and the tongue is the instrument of talking and of what the faculty of speech expresses. [...]. After having rinsed the mouth, the one who performs ritual ablution inhales, that is, puts water in the nostrils $^{25}$ through which fresh air passes. This is why we said that the learned man ('âlim), who benefits from the Lord of his isle [i.e. al-huğğa] ${ }^{26}$ must relate his

24 See al-SIǦISTĀNĪ 1980: 111, 16-19; 112,23-113-1; 2000: 236, 6-10.

25 Here al-Siğistānī seems to evoke al-Qāọī al-Nu'mān (363/974). Regarded as the founder of the IsmailiFatimid jurisprudence, al-Qāḍi al-Nu'mān was also the most authoritative representative in the field of the $t a^{\prime} w \bar{l} l$, to which he devoted the Ta'will al-Da' $a^{\prime} i m$, the esoteric compendium to his masterpiece Da'äim al-Isläm. In discussing the esoteric interpretation of the tahāra, he related the mouth to the imam and understood rinsing the mouth and inhaling water through the nostrils as the acknowledgment of the imam and of his 'proof' (huğğa). See al-QĀDị al-NU'MĀN, Ta'wīl al-Da'ä̉im, cit. in al-SIĞISTĀNī 2000: 417. For details on his concept of bātin see SHAH 2005. For his contribution to the Ismaili jurisprudence see FYZEE 1934; PoONAWALA 1974; PoONAWALA 1977: 48-68; POONAWALA 1996; CiLARDO 2012. For an outline of al-Qāḍi al-Nu'man's view on the pillars of Islam see also HALM 1996: 370-374.

26 Lit. 'proof', this term indicated originally prophets and a'imma, who were considered the proofs of God on earth. Later, the term huğğa was assigned to chief representative of the imam who was charged with the control of a specific region, called 'isle', ğazir $r$. Since the Ismailis were scattered in a wide geographical area, they provided for an elaborated system of control so as to manage and spread their propaganda widely, especially in the territories outside Fatimid provinces, where the da'wa was directed in utmost secrecy. This is why the Ismaili world was divided into 12 'islands' ( $\check{g} a z \bar{a}$ i $i r$, sg. ğazira), each of them under the control of a 'proof' (huğğa), who was assisted by several subordinate $d u^{\prime} \bar{a} t$ of a variety of ranks.

jحis • 17 (2017): 268-279 
knowledge to the Lord [i.e. the Imam] of Time who, thanks to the subtleness of his soul, 'inhales' the inspiration through which the Adjuncts, who are under him in rank, will have [enough] strength to receive it (sc. knowledge) in a common spiritual [way]. So the right hand, the mouth, the nostrils and the water put in them [are] among the customary practices of ritual ablution, although they [must be related] to those we named among the learned appointed men, each of them is above the other in rank. ${ }^{27}$

Therefore, al-Siğistānī maintains that the body needs water to remove its impurities so as to let the muslim perform the exoteric ablution; in the same way, the believer, mu'min, whose search for knowledge is compared to the search for water by one who is thirsty, ${ }^{28}$ needs God's messenger and imam, who are charged with the delivery of knowledge, in order to eliminate ignorance and unbelief so as to perform the esoteric ablution.

It is worth noting that this knowledge cannot be achieved by the common man because it does not derive from senses but it was inspired by God in the eminent (waği h) persons of prophets. This is why, according to al-Siğistānī, washing the face (wağh) in ritual ablution must be understood as obedience to the messenger of God, as quoted in the following passage:

Washing the face is the first of the religious duties of ritual ablution, hence we related it to the obedience towards the messenger [...]. So, we do not commit sin if we mention our messenger when we wash the face, because we think that the obedience to him is a religious duty, just like the religious duty of washing the face during ritual ablution. Is not the face the manifest [aspect] so as to distinguish a man from another? Similarly, the messenger is the virtuous chief known in his era, because he is the prominent personality of his community (wağh ummatihi ) and [the word] wağinh (i.e. eminent) derives from wağh (face). And God, be His mention exalted, called the Messiah, peace be upon him, eminent when He said: ' [...] held in honour in this world and in the Hereafter and of (the company of) those nearest to Allah'. ${ }^{29}$

Hence, the true believer must obey the messenger, who is the mouthpiece of God's word, as well as the imam, who is charged with the custody of Truth.

The religious duty to obey both, messenger and imam, is represented during ritual ablution in washing the face and the hands; according to al-Siğistānı̄'s interpretation the true believer washes first his face and secondly his hands because he must first acknowledge God's messenger and then his legatee.

As mentioned earlier, Ismailism recognises a double interpretation of the Scripture, one exoteric (manifest, zāhir) that pertains to the messenger, and the other esoteric (hidden, bātin), which pertains to the imam. Both aspects, which are not antithetical, are represented

27 al-SiĞISTĀNī 1980: 114,1-7; 2000: 236,15-16; 237,3-9.

28 The relation between water and knowledge is evoked by the term murtād, which al-Siğistānī uses to define who searches for knowledge, because the verb irtäda also indicates a place where food and water abound. See FREYTAG 1975, II: 208b, s.v. rāda.

29 al-SIĞISTĀNī 1980: 114,7-15; 2000: 237,10; 238,1. For the Qur'anic quotation, see 3:45. 
during the rite of ablution in the believer's clothes and hands, which symbolise the laws of Scripture and their hidden Truth respectively.

When the one who performs ritual ablution finishes washing the face, that corresponds to the obedience towards the messenger, he begins to wash the hands that corresponds to the obedience of the believer to the legatee (wasiyy), ${ }^{30}$ who comes after the messenger, the prayer of God on him and on his family, because it is inevitable that the messenger appointed a legatee to his community so as to preserve his religion. And the hands are covered by the clothes because the call to Truth $\left(d a^{c} w a\right)$ of this legatee is hidden and concealed in the laws, which are the visible clothes [that cover] the hands. ${ }^{31}$

In order to perform ritual ablution in the correct way, the true believer must massage his head with water and then wash his feet. In al-Siğistān̄̄'s view, since the head is the seat of the senses to which the Soul is linked: '(God) ordered to pour water on head and to massage it from top to bottom [so as to provide evidence of] the acknowledgment of the noble level (martaba) of the Soul by he who performs ritual ablution'. ${ }^{32}$

As for the feet, their being wiped and washed during the ritual ablution is considered as a deed of submission to the highest rank of the spiritual hierarchy, that is, the Intellect, as the following passage shows:

The feet were put in correspondence with the Intellect, that must be acknowledged through the wiping (mash) and the washing ( $\dot{g} u s l)$ of the feet, and this means that, although the Intellect is far from being achieved with regards to its essence, those who understand ('uqala $\bar{a}^{\text {') }}$ must obey it, lead up to what it has imposed and abstain from what is opposite to it. Hence, massage (mash) is associated to the acknowledgment of it (sc. the Intellect) from those who possess the lowest ranks while washing ( $\dot{g} u s l)$ is connected with the obedience towards it (sc. the Intellect) from those who are endued with understanding $(u l \bar{u}$ al-nuhā $){ }^{33}$

In this way, according to al-Siğistānī, the true believer, through the washing of the head and of the feet, recognises the superiority of the Intellect and the Soul, the spiritual 'archetypes' who have their counterpart in the messenger and his legatee, who are the religious 'archetypes'. ${ }^{34}$

30 As regards the relationship between the hand and the imam, it is worth noting that in the pre-Fatimid period the imam's delegate, who was charged with the control of the ğazira, was named yad, that is, 'hand'. See DAFTARY 1998: 98.

31 al-SIĞISTĀNĪ 1980: 114,16-19; 2000: 238,2-6.

32 al-SIĞISTĀNĪ 1980: 115,8-9; 2000: 239,2-3.

33 al-SIĞISTĀNĪ 1980: 115,13-16; 2000: 239,6-10. As for the expression ulū al-nuhā see Quran 20:54.

34 Both archetypes, spiritual and religious, are considered by al-Siğistān̄̄ as the 'four roots of Truth', which al-Siğistānī represented in the Kitāb al-Yanābi $\bar{\imath}^{c}$ through the image of a cross. At the top of the vertical line there is the Intellect and at the bottom, which is planted in the ground, there is the Foundation, while on the horizontal line al-Siğistānī put the Soul to the left and the Speaking-prophet to the right. See al-SIĞISTĀNĪ, Kitāb al-Yanābī $\bar{c}^{\complement}, 75-76$. Each root is charged with a peculiar function: so, the Intellect is responsible for the inspiration ( $t a^{3} y \bar{i} d$ ) that enables the Foundation to interpret esoterically $\left(t a^{3} w \bar{l} l\right)$ Scripture, on the other hand the Soul is responsible for the composition (tarkỉb) of the physical 


\section{Conclusions}

This paper, which is a continuation of my previous research on the Siğistānian view of the pillars of Islam, has focused attention on the interpretation of cultic purity and ritual ablution that Abū Ya'qūb al-Siğistānī gave in the Kitāb al-iftihāar, an apologia written to reply polemically to the Ismailis' opponents. Despite the exhaustive exegetical literature on the Sunni interpretation on $w u d \bar{u}^{\prime}$ and tahāra, ${ }^{35}$ the present study has analysed the issue in the Ismaili context, focusing on al-Siğistān̄ who, in summarising the basic tenets of Ismaili doctrine in his last work, provided an overview of Ismaili teachings during the more developed phase of their evolution.

As the analysis of some excerpts of the Iftihār has demonstrated, according to alSiğistānī the true meaning of ablution and cultic purity must be understood as the disavowal of the legitimate a’imma from those who seized legal power. In al-Siğistānī's view, this denial is considered the worst of the impurities that must be removed through an act of purification and ablution, both of them to be interpreted metaphorically.

The first step of this ritual requires the achievement of purification through symbolic water, namely knowledge that allows the unveiling of Truth so as to achieve the true understanding of Revelation. As for ablution, its ritual is a symbolic way to acknowledge the religious as well as the normative world, ${ }^{36}$ the double hierarchy that represents a basic feature of the Siğistānian system.

Through ritual ablution and cultic purity, the true believer obeys the imam and acknowledges the necessity for him and for the imamate. This backbone of the Ismaili creed is also represented by the ritual of massage and washing the believer's body, ${ }^{37}$ which

elements into material beings, this is why it is put in relation with the Speaking-prophet who is charged with the composition (ta'liff) of God's Word in Scripture and laws. For a detailed discussion see WALKER 1996: esp. ch. 2.

35 For details on the exegesis of țahära in Sunni context see, among the others, NAGUIB 2007; KATZ 2002: $75 \mathrm{ff}$. As for the state of the studies on this issue and on the interaction of theoretical and lived Islam in ritual and purity laws, see GAUVAIN 2005. I would like to express my gratitude to the anonymous referees who gave me these bibliographical details.

36 Religious world ('âlam al-dìn) is the world created during the historical cycles of prophecy and religion, while normative world ('âlam al-wad ') is the domain of law, which gives religious world a 'moral' direction.

37 In the Kitāb šağarat al-yaqin, a treatise of problematic authorship and date, the human body represents the three parts into which the universe can be divided; as a matter of fact, the head, the torso and the feet are related to the spiritual, the physical and the material world, respectively. In stressing that physical and material worlds cannot do without the spiritual world, the author maintains that: 'There is no evidence that man can exist without head [on the contrary he can exist without a foot], similarly there is no evidence that the two worlds, physical and material, can exist without spiritual world. The first thing of the unborn baby that comes out in the material world is the head, and this provides evidence that the first thing that God, be exalted His mention, installed $\left(a b d a^{c} a\right)$ was the spiritual world [...] and the last thing of the unborn baby that comes out in the material world are his feet and this provides evidence that material world derives from the spiritual world through the mediation of the physical world.' 'ABDĀN (attributed to), Kitāb šağarat al-yaqīn, 66-67. Although not explicitly stated, it seems that the two extremities of the human body, namely the head and feet, can be also connected to the two aspects of the Revelation, that is, zāhir and bātin, which, in their turn, are the distinctive qualities of tanzill and ta'wīl. 
symbolises the religious hierarchy (al-ḥudūd al-ğismāniyya) and its spiritual counterpart (al-ḥudūd al-rūḥāniyya).

These two hierarchies, linked together through a system of symmetric correspondences, assure the 'reductio ad Unum' ( $t a$ 'wīl) to which Ismailism aspires.

\section{Bibliography}

\section{Sources}

al-SıĞISTĀNĪ, Abū Ya'qūb. Kitāb al-Yanābīc / ed. Henri Corbin. In: Trilogie ismaélienne. TeheranParis: Maisonneuve, 1961.

— . Kitāb al-iftihār / ed. Mușțafā Gāālib. Bayrūt: Dār al-Andalus, 1980.

— . Kitāb al-iftihāar / ed. Ismail K. Poonawala. Bayrūt: Dār al-Ġarb al-Islāmī, 1982.

'ABDĀN, al-Dā'ī al-Qurmuțī (attributed to). Kitāb šağarat al-yaqīn / ed. 'Ārif Tāmir. Bayrūt: Dār alĀfāq al-Ǧadīda, 2000.

\section{Secondary works}

Ali, Yusuf (trans.). 2001. The Holy Qur'an, rev. edn. Ware: Wordsworth Editions Ltd.

Biesterfeldt, Hinrich Hans / Klemm, Verena (eds.). 2012. Difference and Dynamism in Islam: Festschrift for Heinz Halm on his 70th Birthday. Würzburg: Ergon.

CILARdo, Agostino. 2012. The History of Ismaili Jurisprudence, Law under the Fatimids: A Critical Edition of the Arabic Text and English Translation of al-Qāḍ̄ al-Nu'mān's Minhāj al-farāidị. London: I.B.Tauris and The Institute of Ismaili Studies.

Craig, Bruce D. (ed.). 2010. Ismaili and Fatimid Studies in Honor of Paul E. Walker. Chicago, IL: Middle East Documentation Center.

DAFTARY, Farhad. 1993, “Da î”. In: Encyclopaedia Iranica: <http://www.iranicaonline.org/articles/ dai-propagandists $>$ (accessed 26 June 2017).

- . (ed.). 1996. Mediaeval Ismai li History and Thought. Cambridge: Cambridge University Press.

— . 1998. A Short History of the Ismailis. Edinburgh: Edinburgh University Press.

— . 2004. Ismaili Literature: A Bibliography of Sources and Studies. London: I.B. Tauris and The Institute of Ismaili Studies.

— . 2010. "Hidden Imams and Mahdis in Ismaili History". In: CRAIG (ed.) 2010: 1-22.

De SMET, Daniel. 2012. "La fonction noétique de la triade al-Jadd, al-Fath and al-Khayāl: Les fondements de la connaissance prophétique dans l'ismaélisme". In: BIESTERFELDT \& KLEMM (eds.) 2012: 319-336.

FREYTAG, Georg Wilhelm Friedrich. 1975. Lexicon Arabico-Latinum. 4 vols. Beirut: Librairie du Liban. (Originally published Halle: C.A. Schwetschke and sons, 1835).

FyZEE, Asaf Ali Asghar. 1934. "Qadi Nu'mān, the Fatimid Jurist and Author". Journal of the Royal Asiatic Society, 66.1: 1-32.

Gauvain, Richard. 2005. "Ritual Rewards: A Consideration of Three Recent Approaches to Sunni Purity Law". Islamic Law and Society, 12.3: 333-393.

HaLm, Heinz. 1996. The Empire of the Mahdi: The Rise of the Fatimids. Translated from German by Michael Bonner. Leiden: Brill.

HämeEn-AntTILA, Jaakko / KoskiKallio, Petteri / LindSTEdT Ilkka (eds.). 2017. Contacts and Interactions. Orientalia Lovaninsia Analecta 254. Leuven: Peeters.

زحi 17 (2017): 268-279 
Katz, Marion H. 2002. Body of Text: The Emergence of the Sunni Law of Ritual Purity. New York: State University of New York Press.

Lawson, Todd (ed.). Reason and Inspiration in Islam: Theology, Philosophy and Mysticism in Muslim Thought. Essay in Honour of Hermann Landolt. London: I.B. Tauris and The Institute of Ismaili Studies.

NAGuib, Shuruq. 2007. "And Your Garments Purify: Tahara in the Light of Tafsir". Journal of Quranic Studies, 9.1: 59-77.

PoONAWALA, Ismail K. 1974. "A Reconsideration of al-Qāḍī al-Nu'mān's madhhab”. Bulletin of the School of Oriental and African Studies, 37: 572-579.

— . 1977. Bibliography of Isma illi Literature. Malibu, CA: Undena Publication.

— . 1996. “Al-Qadi al-Nu'man and Isma'ili Jurisprudence”. In: DAFTARY (ed.) 1996: 117-143.

ReINKOwski, Maurus / WinEt, Monika / YASARgil, Sevinç (eds.). 2016. Arabic and Islamic Studies in Europe and Beyond: Études arabes et islamiques en Europe et au-delà. Orientalia Lovaniensia Analecta 248. Leuven: Peeters.

SHAH, Bulbul. 2005. "Al-Qāḍ̂̄ al-Nu'mān and the Concept of Bāṭin”. In: LAwsON (ed.) 2005: 117126.

STRAFACE, Antonella. 2016a. "The Arkān al-Islām According to al-Siğistānī: Fasting in Waiting for the $Q \bar{a}$ 'im”. In REINKOWSKI, WinET \& YASARGIL (eds.) 2016: 219-228.

- . 2016b. "The Calling to the Roots of Truth: The Prayer in al-Siğistān̄̄s Ismaili View". In: Proceedings of the Congress of the Union Européenne des Arabisants et islamisants. Palermo, 12-16 September 2016. Forthcoming.

—. 2017. "The Duty of being Charitable in Knowledge: The Zakāt in al-Siğistān̄̄’s Kitāb aliftikhār". In: HÄMEEN-ANTTILA, KosKiKALlio \& LinDSTEDT (eds.) 2017: 459-466.

TAJdDIN SADIK Ali, M.A. 2006. "Dā'c-dacwa". In: Encyclopaedia of Ismailism. Karachi: Islamic Book Publisher: <http://ismaili.net/heritage/node/10269> (accessed 26 June 2017).

TUCKER, William F. 2008. Mahdis and Millenarians: Shiite Extremists in Early Muslim Iraq. Cambridge: Cambridge University Press.

Walker, Paul E. 1993. Early Philosophical Shiism: The Ismaili Neoplatonism of Abū Yáqūb alSiǧistānī. Cambridge: Cambridge University Press.

— . 1996. Abū Yáqūb al-Siğistānī: Intellectual Missionary. London: I.B. Tauris.

(C) Antonella Straface, University of Naples "L'Orientale"

4 astraface@unior.it 